Editorial

\title{
Current Research on Embedded DC/DC Converters
}

\author{
Anna Richelli (1)
}

Citation: Richelli, A. Current Research on Embedded DC/DC Converters. Energies 2021, 14, 6142. https://doi.org/10.3390/en14196142

Received: 15 September 2021 Accepted: 24 September 2021 Published: 27 September 2021

Publisher's Note: MDPI stays neutral with regard to jurisdictional claims in published maps and institutional affiliations.

Copyright: (C) 2021 by the author. Licensee MDPI, Basel, Switzerland. This article is an open access article distributed under the terms and conditions of the Creative Commons Attribution (CC BY) license (https:// creativecommons.org/licenses/by/ $4.0 /)$.
Department of Information Engineering, University of Brescia, Via Branze 38, 25123 Brescia, Italy; anna.richelli@unibs.it

In several energy applications, DC/DC converters are one of the most important components. They are used to adapt the voltage level to the need of the load.

This Special Issue is focused, in particular, on integrated DC/DC converters, because these kinds of converters have their own issues and characteristics. For example, in standard CMOS technology, the converters generally reach low-middle efficiency, which is much lower than their non-integrated counterpart. On the other hand, the integration presents the enormous advantages of small area and weight, low power consumption, and fast frequencies and operations. These features make the integrated converters very attractive in a wide field of applications.

For example, compact or fully integrated DC/DC converters play a significant role in the systems of the Internet of Things (IoT). They provide, indeed, energy input interfaces from lithium-ion batteries, next-generation batteries, or various harvesting sources. Furthermore, considering the trends in the miniaturization of IoT devices, the area and power density performances of the DC/DC converters are important, along with their power efficiency over a wide load range.

In [1] a dual-mode DC/DC buck converter, for multi-purpose IoT applications, is presented, which exhibits a good efficiency over a wide load range. Different control strategies are implemented to achieve an optimal efficiency in both light-load and heavyload applications.

The review paper in [2] illustrates the main issues of power converters in IoT. First, it provides an overview about the power consumption in IoT devices; second, it discusses and compares the most advanced architectures (fully integrated or embedded), up to the recent DC/DC converters, for multiple energy sources.

Along with connecting the world, another important task in which DC/DC converters play a major role is harvesting energy from the environment. To this aim, several architectures are designed.

In [3], a novel converter is presented, for boosting the low-voltage output of a thermoelectric energy harvester. The converter starts from $+13 \mathrm{mV} /-13 \mathrm{mV}$ and reaches up to $5 \mathrm{~V}$; it comprises two transformers, one for each polarity, multiplexed between an oscillator (used during startup) and a flyback converter (used during normal operation).

Among the different kinds of energy sources, one of the most used is the photovoltaic (PV) energy source. Moreover, PV technology is the fastest growing technology, due to the cost reduction in manufacturing and government subsidies. The PV global capacity grew from 23 GW in 2009 to more than 600 GW in 2019. On the other hand, the PV system's output power is dependent on solar irradiance and weather, which are both intermittent, and, therefore, in this kind of application, a careful design of the converter and maximum power tracking (MPT) system is mandatory.

Among the different conversion architectures for the PV systems, multilevel inverters (MLI) have become more attractive to researchers, compared to two-level inverters, due to their abilities to provide lower electromagnetic interference, higher efficiency, and larger DC link voltages. In [4], multilevel inverters are discussed and compared, based on their classifications, development, and challenges, with practical recommendations in utilizing them in renewable energy systems. 
The work illustrated in [5] presents a family of high-voltage-gain three-level boost converters that are suitable for photovoltaic energy integration. The family enhances the three-level boost converter by adding high-voltage boosting techniques, including switched-inductor cells and coupled inductors. An example of a three-level boost converter with a flyback transformer is analyzed, simulated, and experimentally implemented, to convert $20 \mathrm{~V}$ to $200 \mathrm{~V}$, with a peak efficiency of about $95 \%$. The converter also extracts the maximum power from photovoltaic panels, using the perturb and observe ( $\mathrm{P} \& \mathrm{O})$ tracking algorithm.

For the power converters, another emerging field of applications is the OLED driver circuits. In recent years, progress in the cost and production of OLED materials has greatly improved, in terms of efficiency and yield, and engineers are required to design ad hoc power supply drivers.

The paper in [6] proposes a single-stage single-ended primary inductor converter (SEPIC) circuit, which is applied to the organic light-emitting diodes (OLED) driver circuit. The proposed circuit replaces the output Schottky diode from the original SEPIC with a power switch. Deadtime is added to prevent the on-state overlapping of two switches with zero-voltage switching (ZVS), and the circuit operates in a triangular current mode.

Finally, the following two general issues in DC/DC converters can conclude this short editorial: they are the comparison between switching capacitors and inductor-based topologies (fully depicted in [7]), and the stability issue, which is very important, especially considering advanced and complex architectures [8].

Conflicts of Interest: The author declares no conflict of interest.

\section{References}

1. Kim, M.W.; Kim, J.J. A PWM/PFM Dual-Mode DC-DC Buck Converter with Load-Dependent Efficiency-Controllable Scheme for Multi-Purpose IoT Applications. Energies 2021, 14, 960. [CrossRef]

2. Richelli, A.; Salem, M.; Colalongo, L. A Review of Fully Integrated and Embedded Power Converters for IoT. Energies 2021, 14, 5419. [CrossRef]

3. Dillersberger, H.; Deutschmann, B.; Tham, D. A Bipolar $\pm 13 \mathrm{mV}$ Self-Starting and $85 \%$ Peak Efficiency DC/DC Converter for Thermoelectric Energy Harvesting. Energies 2020, 13, 5501. [CrossRef]

4. Bughneda, A.; Salem, M.; Richelli, A.; Ishak, D.; Alatai, S. Review of Multilevel Inverters for PV Energy System Applications. Energies 2021, 14, 1585. [CrossRef]

5. Alzahrani, A.; Shamsi, P.; Ferdowsi, M. A Family of High Voltage Gain Three-Level Step-Up Converters for Photovoltaic Module Integration Applications. Energies 2020, 13, 6115. [CrossRef]

6. Lin, Z.-R.; Chiu, H.-J. Design and Implementation of Solar OLED Lighting Driver Circuit with Frequency Modulation Control. Energies 2020, 13, 5608. [CrossRef]

7. Kiran Kumar, G.; Kobaku, T.; Sahoo, S.; Subudhi, B.; Elangovan, D.; Blaabjerg, F. An Overview of Fully Integrated Switching Power Converters Based on Switched-Capacitor versus Inductive Approach and Their Advanced Control Aspects. Energies 2021, 14, 3250. [CrossRef]

8. Huang, C.-C.; Yao, S.-L.; Chiu, H.-J. Stability Analysis and Optimal Design for Virtual Impedance of 48 V Server Power System for Data Center Applications. Energies 2020, 13, 5253. [CrossRef] 